\title{
A National Survey of Primary Care Practice-Based Research Networks
}

\author{
William M. Tierney, $M D^{1,2}$ \\ Caitlin C. Oppenbeimer, $M P H^{3,4}$ \\ Brenda L. Hudson, MA ${ }^{1}$ \\ Jennifer Benz, $B A^{3,4}$ \\ Amy Finn, $B A^{1}$ \\ Jobn M. Hickner, $M D^{4}$ \\ David Lanier, $M D^{5}$ \\ Daniel S. Gaylin, $M P A^{3,4}$
}

'Division of General Internal Medicine and Geriatrics, Indiana University School of

Medicine, Indianapolis, Ind

${ }^{2}$ Regenstrief Institute, Inc, Indianapolis, Ind

${ }^{3}$ National Opinion Research Center, Washington, DC

${ }^{4}$ Department of Family Medicine, The University of Chicago, Chicago, Ill

${ }^{5}$ Agency for Healthcare Research and Quality, Gaithersburg, Md

Conflicts of interest: none reported

\section{CORRESPONDING AUTHOR}

William M. Tierney, MD Room M200-OPW 1001 West Tenth Street Indianapolis, IN 46202 wtierney@iupui.edu

\begin{abstract}
PURPOSE Increasing numbers of primary care practice-based research networks (PBRNs) are being developed in the United States to perform research relevant to everyday practice. To assess the current status and potential value of this resource, we surveyed US primary care PBRNs in operation from late 2003 to early 2004.
\end{abstract}

METHODS We performed a Web-based survey and structured interviews with PBRN directors and administrative officers, assessing PBRNs' history, size, location, organization, resources, operations, and productivity (funding obtained, studies performed, and articles published).

RESULTS Of 111 primary care PBRNs identified, 89 (80\%) responded to the survey. The 86 (77\%) meeting the criteria for primary care PBRNs contained 1,871 practices, 12,957 physicians (mean 152 per PBRN, median 100), and 14.7 million patients (mean 229,880 per PBRN, median 105,000). Minority and underinsured patients were overrepresented. The average PBRN was young ( $4.4 \pm 5.7$ years): one-half had performed 3 or fewer studies. Three-quarters were affiliated with universities. Common research foci included prevention, diabetes, cardiovascular risk factors, and mental health. Respondent PBRNs had published more than 600 articles in peer-reviewed journals. PBRNs studying questions posed by outside researchers had more federal funding ( $84 \%$ vs $27 \%, P=.006)$. PBRNs citing funding as a weakness relied more on local resources to fund research projects (70\% vs $40 \%, P=.036)$.

CONCLUSIONS American primary care PBRNs are mainly young, diverse, and pursuing a variety of research foci. Most have university links and provide a dynamic town-gown relationship that could be a vital national resource for improving primary care, translating research into practice, and meeting the National Institutes of Health Roadmap goals. PBRNs merit further attention from both private and public funding agencies and researchers interested in studying the delivery of primary care.

Ann Fam Med 2007;5:242-250. DOI: 10.1370/afm.699.

\section{INTRODUCTION}

T $\mathrm{n}$ its landmark indictment of the quality of health care in the United States, the Institute of Medicine lamented that many proven effective treatments do not become incorporated into everyday care. ${ }^{1}$ One review showed that only $14 \%$ of research findings filter down to everyday practice, and those that do take an average of 17 years. ${ }^{2}$ In 2003 Elias Zerhouni, director of the National Institutes of Health (NIH), responded by increasing the NIH's emphasis on translation of research into practice, establishing new research networks as a major step in NIH's Roadmap for Re-Engineering the Clinical Research Enterprise. ${ }^{3}$

The disconnect between research and everyday practice is in large part because most research is performed in academic medical centers, where less than $1 \%$ of Americans visiting physicians receive their health care. ${ }^{4}$ Such research often excludes patients commonly seen in community-based primary care: elders, patients with multiple medical conditions, patients 
nonadherent to treatment, and those suffering from substance abuse or psychiatric disorders. ${ }^{5}$ Studies performed in academic centers also tend to examine patient and clinician behaviors under controlled situations. It is not surprising, then, that the results of such studies are often not applicable to many communitybased primary care patients or their clinicians. Kroenke et $a l^{6}$ have shown that most patients seeking primary care have nonspecific complaints to which the results of published research may not be relevant. Thus, primary care physicians trying to practice evidence-based medicine are frequently hampered by having little evidence to apply to the problems they face. As a consequence, their patients often leave unsatisfied. ${ }^{7}$

There are therefore 2 major disconnects between research and practice: research may not translate expeditiously to everyday practice, and clinical problems encountered in everyday practice are often underinvestigated. PBRNs were established in the United Kingdom in the 1960s to overcome these disconnects and subsequently spread to other European countries. ${ }^{9}$ The first major PBRNs in the United States came in the 1970s: the Family Medicine Information System ${ }^{10}$ and the Cooperative Information Project. ${ }^{11}$ These PBRNs were comprised mainly of community-based family medicine practices that had joined together to perform research relevant to the problems of delivering community-based primary care. In the United States, however, where federally funded research remained focused on academic medical centers, PBRNs have been slow to catch on.

In 2000, Congress responded by charging the Agency for Healthcare Research and Quality (AHRQ) to identify and support primary care practice-based research networks as a resource for accelerating the translation of research into practice and performing research relevant to everyday primary care. ${ }^{8}$ This act specifically states:

In order to address the full continuum of care and outcomes research, to link research to practice improvement, and to speed the dissemination of research findings to community practice settings, the Agency shall employ research strategies and mechanisms that will link research directly with clinical practice in geographically diverse locations throughout the United States, including ... provider-based research networks, including plan, facility, or delivery system sites of care (especially primary care), that can evaluate outcomes and evaluate and promote quality improvement....

AHRQ pursued this congressional directive by providing specific funding opportunities for primary care PBRNs, first in 2000 and again in 2002. The first round offered 19 PBRNs 1-year grants to "assist new or established PBRNs in planning for activities to enhance their capacity to conduct research in primary care settings and translate research findings into prac- tice." AHRQ also collaborated with the Robert Wood Johnson Foundation to fund additional PBRNs to participate in a multisite research project focused on promoting healthy behaviors among patients in primary care settings. ${ }^{12}$ More than 100 PBRNs applied for these funding opportunities, suggesting to AHRQ that there was an expanding number of PBRNs that might help fulfill their congressional mandate to translate research into everyday practice. To identify and describe existing US primary care PBRNs, AHRQ funded this systematic survey of all active primary care PBRNs in the United States. The goal was to describe their diversity in specialty, structure, function, and history, as well as their potential for translating research into practice and answering questions of importance to primary care practitioners and their patients.

\section{METHODS}

This study was approved by the institutional review boards of Indiana University and the National Opinion Research Center. In the fall of 2003, we identified currently active primary care PBRNs that had all the following criteria established by AHRQ in its PBRN initiative ${ }^{13}$ :

- A director

- A formal administrative structure that transcended individual studies

- At least 15 separate primary care practices or clinicians

- More than $50 \%$ of the members practicing primary care in the United States

- Some mechanism for soliciting advice and feedback from the community of patients served by the network's clinicians

To find primary care PBRNs, we looked for those currently or previously funded by AHRQ or the Robert Wood Johnson Foundation's Prescription for Health Initiative, ${ }^{12}$ those belonging to the Federation of Practice Based Research Networks (the Federation) affiliated with the American Academy of Family Physicians, ${ }^{14}$ those we found through published articles, and as many other PBRNs as we could find through discussions with AHRQ, leaders of the Federation, and existing PBRNs.

We developed a Web-based questionnaire that collected the following information from the PBRNs' director and/or administrator: descriptions of the PBRN (name, office location, age, administrative structure); the member practices and clinicians (number and locations of practices, number of physicians or other primary care clinicians, and clinicians' medical specialties); patients served (number per practice and demographic data including age, sex, race/ethnicity, insurance status, if known); types and sources of research funding; productivity (number of studies performed and num- 
ber of subjects included); and research foci, including research themes (eg, specific population age or research methodology) and specific diseases and nondisease health conditions (based on a closed-ended list of common research foci). We also queried the PBRN directors or administrators on self-assessed strengths and weaknesses, whether their member practices had incorporated research results into their practices, and barriers to translating research into practice. Response categories were developed based on the research teams knowledge of practicing PBRNs. Thirty-five of the 45 questions were closed-ended to facilitate efficient completion of the questionnaire and data analysis. The survey questionnaire was pilot tested with 5 PBRNs and revised to reflect their input on interpretability, clarity, and feasibility of completion. The final instrument is available from the authors upon request.

We administered the questionnaire using UltimateApps (Prezza Technologies, Cambridge, Mass) by sending an e-mail to the director of each PBRN we identified, and we invited him or her to complete the questionnaire by clicking on a link to the survey Web site. Each director gave consent on the first page before proceeding to the questionnaire. We sent reminders to all PBRN directors who did not complete the questionnaire within 1 month. After 1 additional month, one of the authors called each nonresponding PBRN director and invited him or her to complete the questionnaire; if desired, they could complete it on paper and return it by mail or fax.

After a PBRN director or administrator completed the questionnaire, we invited the director to participate in a semistructured telephone interview using a standard protocol that included questions about current and anticipated research projects, decisionmaking procedures at the network, current challenges facing the network, and potential interest in participation in a national study. Qualitative data from the telephone conversations were used to supplement the survey data and, in some cases, complete missing items from the questionnaire.

We tabulated and analyzed all data using SAS version 8.02 (SAS Institute, Carey, NC). We assessed differences using corrected $\chi^{2}$ tests and Fisher exact tests for categorical variables and Student $t$ tests for continuous variables. Differences associated with $P$ values $>.05$ were considered statistically significant. When cell sizes were small, we collapsed multilevel variables to create the most relevant dichotomous variables.

\section{RESULTS}

We found 111 primary care PBRNs that met our inclusion criteria; 89 (80\%) completed the questionnaire.
Three did not meet the criteria for a primary care PBRN and were excluded. The locations of the administrative offices of the final 86 PBRNs (77\% of the 111 originally contacted) are shown in Figure 1. (The 86 PBRNs providing data and their locations are listed in the online-only Supplemental Appendix, which can be found at: http://www.annfammed.org/cgi/content/ full/5/3/242/DC1). At the time of this survey, these 86 PBRNs included 1,871 practices, 12,957 physicians (mean $152 \pm 229$, median 100, range 15-1,760), and 14.7 million patients (mean 229,880 $\pm 424,880$, median 105,000, range 1,200 to 2.7 million). Eighty PBRNs (90\% of respondents) provided addresses for all of their practices, and the 46 AHRQ-funded PBRNs provided detailed information on their practices, clinicians, and patients and completed semistructured telephone interviews. As shown in Figure 1, the 68 PBRNs providing practice addresses had member practices in all 50 states and Puerto Rico, although the heaviest concentrations were in the eastern states and the Midwest. Three PBRNs were nationwide, with member practices in multiple states and affiliated with professional organizations: the American College of Physicians, the American Academy of Family Physicians, and the American Pediatrics Association. The rest had practices in a single state or adjoining states.

\section{PBRN Characteristics}

There were 4 primary care specialties represented in PBRN practices: family medicine, pediatrics, general internal medicine, and family nurse-practitioners. As shown in Table 1, 33 (38\%) of responding PBRNs were made up of clinicians with a single primary care specialty, the most common being family medicine. Of the 53 primary care PBRNs having clinicians from multiple primary care specialties, almost all included family physicians, whereas three-quarters included pediatricians and internists. Nearly all 86 responding PBRNs provided care to pediatric patients either through clinicians trained as pediatricians or family medicine specialists.

On average, respondent primary care PBRNs were young: they had been functioning for a mean of $4.4 \pm 5.7$ years, median of 3 years, range $<1$ to 32 years (Table 1 ). Three-quarters were affiliated with a university; most others were affiliated with a nonprofit or professional organization. Most received some support (direct and indirect) from their affiliated organizations. Funding for PBRN studies came from a variety of sources. Most PBRNs received project-specific funding from federal agencies and from their sponsoring organizations, whereas one-half also received projectspecific funding from foundations.

Originally PBRNs were established as a structure 


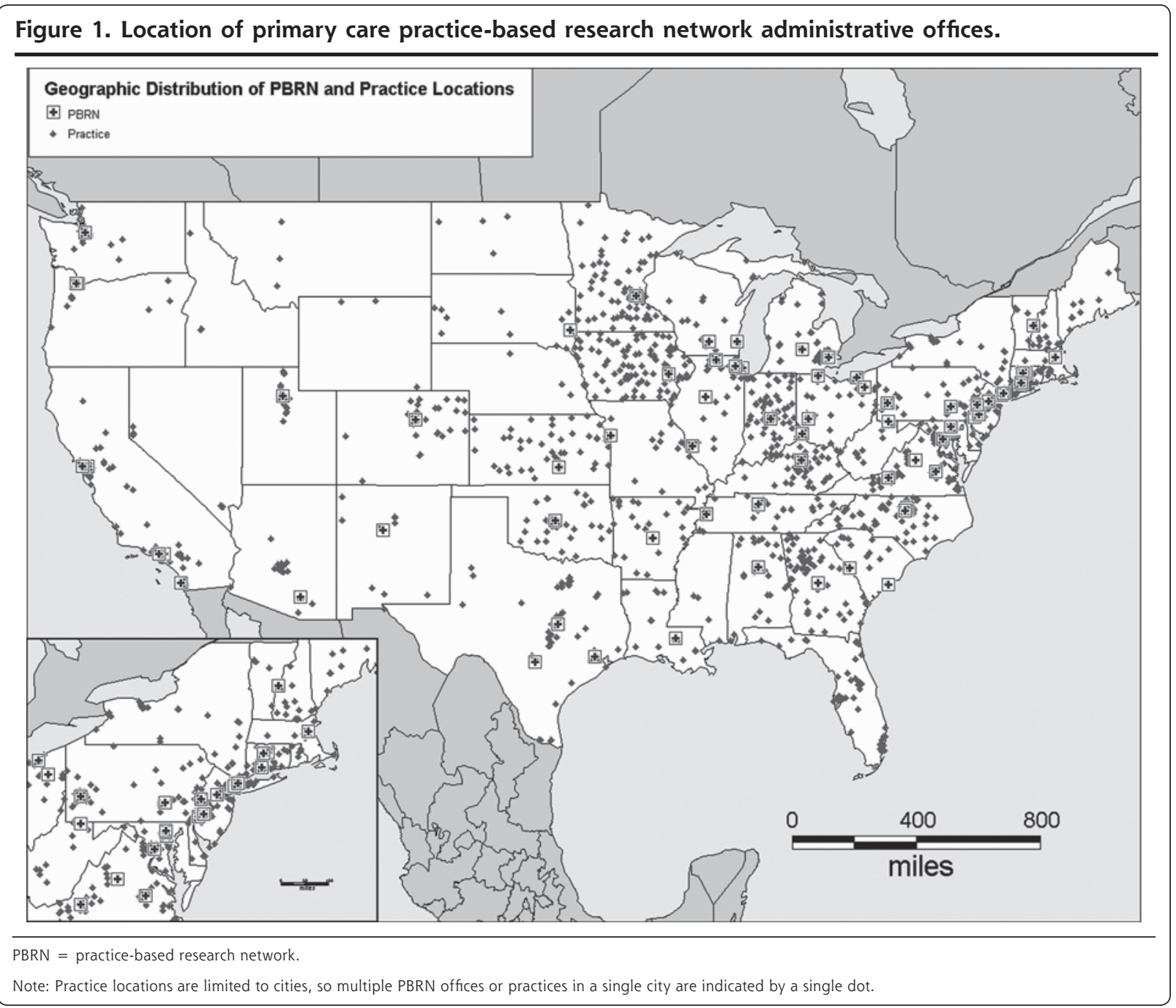

in which their members could perform research ${ }^{15}$; however, only 1 in 7 of the responding PBRNs relied solely on their leaders or members for research ideas (so-called bottom-up PBRNs). For one-quarter of respondent PBRNs, research ideas came mainly from outside investigators (top-down). Most relied on both their members and outside investigators for generating research ideas. Of note, only $27 \%$ of the self-described bottom-up PBRNs had ever received federal funding for research compared with $84 \%$ of PBRNs having a top-down or mixed method for generating research proposals $(P=.006)$.

Sixty PBRNs reported having a general research theme, the most common being a specific disease or treatment. A substantial minority focused on a particular research method, such as interventional or observational studies. Eight-five PBRNs reported on the clinical focus of their research, the most common being prevention, diabetes, cardiovascular risk, and mental health.

\section{Patient Characteristics}

Sixty PBRNs (70\% of respondents) provided demographic information on the patients in their practices (Table 2). Compared with 2002 national population estimates $^{16}$ and persons seeking health care (as determined by the National Health Interview Study), ${ }^{17}$ PBRNs serve a more diverse patient population. PBRN patients tended to be slightly younger than the general population and more often of minority race and of Hispanic ethnicity compared with both the general population and persons seeking health care. PBRN patients have lower socioeconomic status (as indicated by a greater share of patients having insurance through state or federal programs, mainly Medicaid) than the general population seeking care.

\section{Research Experience}

As multi-institutional collaborations, PBRNs sometimes face complicated research governance issues. Nearly one-half reported being covered by more than 1 insti- 
Table 1. Practice-Based Research Network (PBRN) Characteristics ( $\mathrm{N}=86$ )

\begin{tabular}{|c|c|}
\hline Characteristic & No. (\%) \\
\hline \multicolumn{2}{|l|}{ Single-specialty PBRNs $(n=33)$} \\
\hline Family medicine & $20(61)$ \\
\hline Pediatric & $10(30)$ \\
\hline Family nurse-practitioner & $2(6)$ \\
\hline General internal medicine & $1(3)$ \\
\hline Obstetrics, gynecology, and midwifery & $1(3)$ \\
\hline \multicolumn{2}{|l|}{ Multispecialty PBRNs $(n=53)$ : specialty of PBRN physicians } \\
\hline Family medicine & $51(96)$ \\
\hline Pediatric & $38(72)$ \\
\hline General internal medicine & $38(72)$ \\
\hline Other specialties (PhDs, dentists, specialized medicine) & $21(40)$ \\
\hline Family nurse-practitioner & $7(13)$ \\
\hline \multicolumn{2}{|l|}{ Affiliation } \\
\hline University & $65(76)$ \\
\hline Nonprofit organization & $9(10)$ \\
\hline Professional organization & $6(7)$ \\
\hline Other, none, or not stated & $6(7)$ \\
\hline \multicolumn{2}{|l|}{ Support from affiliated organization (of 83 with an affiliation) } \\
\hline Direct & $8(10)$ \\
\hline Indirect & $12(14)$ \\
\hline Both & $39(47)$ \\
\hline Neither direct nor indirect & $19(23)$ \\
\hline Not stated & $5(6)$ \\
\hline \multicolumn{2}{|l|}{ Funding for PBRN studies (multiple responses allowed) } \\
\hline Federal funding agency, project-specific & $72(84)$ \\
\hline $\begin{array}{l}\text { Home institution (eg, university, or nonprofit or } \\
\text { professional organization) }\end{array}$ & $64(74)$ \\
\hline Foundation, project-specific & $48(56)$ \\
\hline Professional organization & $21(24)$ \\
\hline Philanthropic & $15(17)$ \\
\hline Other unspecified source of funds & $8(9)$ \\
\hline \multicolumn{2}{|l|}{ Source of research ideas ( $n=85$ reporting) } \\
\hline PBRN leaders and clinicians (bottom-up) & $12(14)$ \\
\hline Outside investigators (top-down) & $23(27)$ \\
\hline Both PBRN leaders/clinicians and outside investigators & $50(59)$ \\
\hline \multicolumn{2}{|l|}{ General research theme (multiple responses allowed) } \\
\hline Methodology: Interventional studies & $25(29)$ \\
\hline Methodology: observational studies & $23(27)$ \\
\hline Specific population: age & $14(16)$ \\
\hline Specific population: ethnicity & $14(16)$ \\
\hline Specific population: urban/rural & $12(14)$ \\
\hline Specific population: race & $11(13)$ \\
\hline No general theme & $25(29)$ \\
\hline \multicolumn{2}{|c|}{ Health condition or treatment focus (multiple responses allowed) } \\
\hline Preventive medicine & $48(56)$ \\
\hline Diabetes & $41(48)$ \\
\hline Cardiovascular risk factors & $29(34)$ \\
\hline Mental health & $26(30)$ \\
\hline Heart disease & $21(24)$ \\
\hline Cancer & $21(24)$ \\
\hline Lung disease & $16(19)$ \\
\hline Substance abuse & $10(12)$ \\
\hline No condition or treatment focus & $10(12)$ \\
\hline
\end{tabular}

tutional review board (Table 3). Whereas the majority indicated they had to interact with between 1 and 5 institutional review boards, a substantial minority reported their practices were covered by more than 6 . Additionally, one-third of PBRNs report they had more than 1 source for human subjects certification.

Slightly more than one-half of the respondent PBRNs were actively engaged in research at the time of the survey, and one-quarter reported not having completed a study (Table 3 ). Of the 45 PBRNs with at least 1 completed study, $38 \%$ completed between 1 and 3,38\% completed 4 to 7 , and $24 \%$ completed more than 7. Currently, the AHRQ National Resource Center for Practice-Based Research Networks has compiled a list of more than 600 peer-reviewed articles emanating from research performed in primary care PBRNs (available from the authors upon request). Of the 46 PBRNs with at least 1 prior or ongoing study, $38(83 \%)$ had enrolled more than 100 patients in their largest study, whereas $20(53 \%)$ had enrolled more than 1,000 patients (Table 3). The mean number of patients enrolled in each PBRN's largest study was 2,279 (median 707). Three PBRNs (Crozer-Keystone Health Network, Pediatric Research in Office Set-

Table 2. Demographic Characteristics of PBRN Patients' Compared With National Benchmarks

\begin{tabular}{|c|c|c|c|}
\hline Characteristic & $\begin{array}{c}\text { PBRN } \\
\text { Patients* } \\
\%\end{array}$ & $\begin{array}{c}\text { National } \\
\text { Figures }^{\dagger} \\
\%\end{array}$ & $\begin{array}{c}\text { Persons } \\
\text { Seeking } \\
\text { Health Care }{ }^{\ddagger} \\
\%\end{array}$ \\
\hline Sex (female) & 57 & 51 & 60 \\
\hline \multicolumn{4}{|l|}{ Age } \\
\hline $1-18 y$ & 34 & 26 & NA \\
\hline $19-59 y$ & 48 & 61 & NA \\
\hline$\geq 60 y$ & 18 & 16 & NA \\
\hline \multicolumn{4}{|l|}{ Race } \\
\hline White & 64 & 81 & 85 \\
\hline African American & 23 & 13 & 10 \\
\hline Native American & 2 & 1 & 1 \\
\hline $\begin{array}{l}\text { Asian/Pacific } \\
\text { Islander }\end{array}$ & 5 & 4 & 2 \\
\hline Other race & 6 & 1 & 2 \\
\hline Hispanic ethnicity & 18 & 13 & 14 \\
\hline \multicolumn{4}{|l|}{ Health insurance } \\
\hline Private & 45 & 71 & 75 \\
\hline State or federal & 42 & 14 & 18 \\
\hline No insurance & 13 & 14 & 7 \\
\hline $\begin{array}{l}\text { PBRN }=\text { practice-based } \\
\text { * Mean value among } 60 \\
\text { † Data from July 1, } 200 \\
\text { Population Estimates - } \\
\text { Bureau. Release Date: Ju } \\
\text { † Blackwell DL, Tonthat } \\
\text { National Health Intervie } \\
\text { Statistics. Vital Health Sta }\end{array}$ & $\begin{array}{l}\text { search network; } \\
\text { PBRNs reportino } \\
\text { published in Ta } \\
\text { aracteristics Sou } \\
\text { 18, } 2003 \text {. } \\
\text { Summary heal } \\
\text { Survey, } 1999 . \\
\text { 2003;10:211. }\end{array}$ & $\begin{array}{l}\text { NA = not avail } \\
\text { patient data. } \\
\text { le NA-EST200 } \\
\text { rce: Population } \\
\text { statistics for t } \\
\text { able 20. Natior }\end{array}$ & $\begin{array}{l}\text { ASRO-02. National } \\
\text { Division, US Census } \\
\text { e U.S. population: } \\
\text { Center for Health }\end{array}$ \\
\hline
\end{tabular}


tings, and Research Association of Practicing Physicians) had each enrolled more than 10,000 patients in a single study. Practice personnel were often involved in recruiting research subjects (Table 3 ): more than one-half of PBRNs reported that the primary person recruiting subjects was a practice clinician, nurse, or clerk; and three-quarters used a research assistant dedicated to either the project or the practice.

Table 4 contains examples of active research projects at the time of the survey that the authors believe represent the spectrum of PBRN research. They were

\begin{tabular}{|c|c|}
\hline Characteristic & $\begin{array}{l}\text { PBRNs } \\
\text { No. }(\%)\end{array}$ \\
\hline \multicolumn{2}{|l|}{ All practices covered by IRB ( $\mathrm{n}=84$ reporting) } \\
\hline No & $14(17)$ \\
\hline Yes - single IRB & $28(33)$ \\
\hline Yes - multiple IRBs & $39(46)$ \\
\hline Unsure & $3(4)$ \\
\hline \multicolumn{2}{|l|}{$\begin{array}{l}\text { No. of separate IRBs covering the practices } \\
(\mathrm{n}=23 \text { reporting) }\end{array}$} \\
\hline $1-5$ & $13(57)$ \\
\hline $6-20$ & $5(22)$ \\
\hline $20+$ & $1(4)$ \\
\hline Unsure & $4(17)$ \\
\hline \multicolumn{2}{|l|}{$\begin{array}{l}\text { Single source for human subjects certification } \\
(\mathrm{n}=43 \text { reporting) }\end{array}$} \\
\hline Yes & $25(58)$ \\
\hline No & $14(33)$ \\
\hline Unknown & $4(9)$ \\
\hline \multicolumn{2}{|c|}{ PBRNs with research experience ( $n=85$ reporting) } \\
\hline Active study now, never in past & $4(5)$ \\
\hline Active study now and at least 1 prior study & $45(53)$ \\
\hline At least 1 prior study, but none now & $21(25)$ \\
\hline Neither an active study nor prior study & $12(14)$ \\
\hline \multicolumn{2}{|l|}{ No. of studies completed ( $n=56$ reporting) } \\
\hline No studies completed & $15(27)$ \\
\hline $1-3$ studies completed & $17(30)$ \\
\hline 4-7 studies completed & $17(30)$ \\
\hline$>7$ studies completed & $11(20)$ \\
\hline \multicolumn{2}{|l|}{$\begin{array}{l}\text { No. of subjects in largest study ( } n=46 \text { reporting } \\
\text { recruiting patients into a study) }\end{array}$} \\
\hline $1-100$ & $8(17)$ \\
\hline $101-500$ & $16(35)$ \\
\hline $501-1,000$ & $2(4)$ \\
\hline$>1,000$ & $20(43)$ \\
\hline \multicolumn{2}{|l|}{$\begin{array}{l}\text { Persons who recruited subjects in past research } \\
(\mathrm{n}=85 \text { reporting) (multiple responses allowed) }\end{array}$} \\
\hline Clinician & $40(47)$ \\
\hline Study's research assistant & $37(44)$ \\
\hline Practice's research assistant & $35(41)$ \\
\hline Practice nurse & $24(28)$ \\
\hline Practice clerk & $11(13)$ \\
\hline Other & $13(15)$ \\
\hline
\end{tabular}

a mixture of health services research, prevention research, and research answering clinical questions. PBRN projects often focused on improving clinical practice and patient outcomes in areas where there is a known intervention that has been shown to be effective in some situations but is not a routine aspect of everyday clinical practice.

\section{Strengths and Weaknesses}

Reflecting the diversity of network experience, community involvement was listed as a self-reported strength for one-third of the respondent PBRNs (Table 5), but it was listed as a weakness by one-quarter of them. In semistructured interviews, those PBRNs identifying community involvement as a weakness generally indicated that they lacked the infrastructure to engage the community and were seeking information from colleagues listing community involvement as a strength. Those networks with a community advisory board had found them helpful in identifying cogent research questions. Similarly, research experience was the second most common strength, whereas lack of research experience was the fourth most common weakness. Lack of information technology was also a common weakness.

Difficulty in securing funding, however, was by far the most commonly listed weakness, selected by onehalf of the PBRNs responding. Of these, 70\% relied upon local funding for research support compared with $40 \%$ of those not citing funding as a weakness $(P=.036)$. Conversely, only $51 \%$ of PBRNs listing funding as a weakness had received federal funding for research compared with $82 \%$ of those not listing funding as a weakness $(P=.016)$. In semistructured interviews, frustration was exhibited by a number of PBRN leaders over the difficulty of maintaining research infrastructure (space, personnel, equipment) between funded studies.

\section{DISCUSSION}

A substantial number of primary care PBRNs were extant in 2003. Their wide geographic distribution and involvement of all primary care specialties make them a strong potential resource for performing research that is relevant to practicing primary care clinicians. Many are young, however, most are affiliated with universities, and poor and minority patients are overrepresented in their practices. Thus, this potential resource will need cultivation before it matures as a potent tool to meet the NIH Roadmap goals ${ }^{3}$ and the AHRQ congressional mandate of addressing the full continuum of care, linking research to practice improvement, and speeding the dissemination of research findings to community practice settings. 


\begin{tabular}{|c|c|c|c|}
\hline Project Type & Project Title & Description & Name of PBRN \\
\hline $\begin{array}{l}\text { Health services } \\
\text { research }\end{array}$ & $\begin{array}{l}\text { How community pedi- } \\
\text { atricians use elec- } \\
\text { tronic technology }\end{array}$ & $\begin{array}{l}\text { A survey of community pediatricians in a practice-based research net- } \\
\text { work using a self-administered form to describe how they use elec- } \\
\text { tronic technology for work-related tasks, level of competence for spe- } \\
\text { cific technology-related activities, and interest in learning these skills }\end{array}$ & $\begin{array}{l}\text { Washington Univer- } \\
\text { sity Pediatric/Ado- } \\
\text { lescent Research } \\
\text { Consortium }\end{array}$ \\
\hline Clinical research & $\begin{array}{l}\text { Child self-reporting } \\
\text { asthma symptoms }\end{array}$ & $\begin{array}{l}\text { Asking the question, "When is it appropriate for children to report for } \\
\text { themselves?" this study aims to assess the acceptability, feasibility, } \\
\text { and psychometric quality of administering asthma-related quality-of- } \\
\text { life questionnaires to children }\end{array}$ & $\begin{array}{l}\text { Cincinnati Pediatric } \\
\text { Research Group }\end{array}$ \\
\hline Clinical research & $\begin{array}{l}\text { Pediatricians recogni- } \\
\text { tion of maternal } \\
\text { depressive symptoms }\end{array}$ & $\begin{array}{l}\text { A project examining the factors that influence pediatricians' recognition } \\
\text { of depressive symptoms in mothers with young children. It aims to } \\
\text { develop and pilot an intervention that addresses barriers to recogni- } \\
\text { tion in the pediatric primary care setting and improve pediatrician's } \\
\text { ability to recognize and refer mothers with depressive symptoms }\end{array}$ & $\begin{array}{l}\text { Rainbow Research } \\
\text { Network }\end{array}$ \\
\hline $\begin{array}{l}\text { Health services } \\
\text { research }\end{array}$ & $\begin{array}{l}\text { Defining patient visits } \\
\text { study }\end{array}$ & $\begin{array}{l}\text { A study to learn about patients and problems seen in "typical practice" } \\
\text { and to allow for a comparison of data with national survey data and } \\
\text { an assessment of the extent to which study practices represent the } \\
\text { nation's pediatric practices }\end{array}$ & $\begin{array}{l}\text { Pediatric Research in } \\
\text { Office Settings }\end{array}$ \\
\hline $\begin{array}{l}\text { Prevention } \\
\text { research }\end{array}$ & $\begin{array}{l}\text { How patients decide } \\
\text { on prostate cancer } \\
\text { screening }\end{array}$ & $\begin{array}{l}\text { Evaluation of shared decision making around prostate cancer screen- } \\
\text { ing to determine the effect of viewing a Web page or mailed bro- } \\
\text { chure on prostate cancer screening on the decision-making process } \\
\text { between a patient and physician }\end{array}$ & $\begin{array}{l}\text { Virginia Ambulatory } \\
\text { Care Outcomes } \\
\text { Research Network }\end{array}$ \\
\hline $\begin{array}{l}\text { Prevention } \\
\text { research }\end{array}$ & $\begin{array}{l}\text { Multilevel approaches } \\
\text { to colon cancer } \\
\text { screening }\end{array}$ & $\begin{array}{l}\text { An exploratory study designed to investigate the effectiveness of strat- } \\
\text { egies to increase colorectal cancer screening in rural family practices. } \\
\text { The primary outcome is the rate of adherence with the US Multi-Soci- } \\
\text { ety Task Force on Colorectal Cancer }\end{array}$ & $\begin{array}{l}\text { Arkansas Research } \\
\text { Collaborative }\end{array}$ \\
\hline $\begin{array}{l}\text { Prevention } \\
\text { research }\end{array}$ & $\begin{array}{l}\text { Improving colorectal } \\
\text { cancer (CRC) screen- } \\
\text { ing in primary care }\end{array}$ & $\begin{array}{l}\text { A study to characterize CRC screening practices across a variety of pri- } \\
\text { mary care clinics of a practice-based research network. It will provide } \\
\text { information about the relationship between practice characteristics } \\
\text { and CRC screening delivery and short-term outcomes }\end{array}$ & $\begin{array}{l}\text { Oklahoma Physicians } \\
\text { Resource/Research } \\
\text { Network }\end{array}$ \\
\hline $\begin{array}{l}\text { Prevention } \\
\text { research }\end{array}$ & Osteoporosis study & $\begin{array}{l}\text { A study designed to determine whether chart reminders or patient } \\
\text { education information for osteoporosis screening improved discus- } \\
\text { sion and treatment of low bone density in older women. Preliminary } \\
\text { analysis shows that chart reminders, but not patient education, } \\
\text { improved osteoporosis discussion and screening }\end{array}$ & $\begin{array}{l}\text { lowa Research } \\
\text { Network }\end{array}$ \\
\hline $\begin{array}{l}\text { Health services } \\
\text { research }\end{array}$ & $\begin{array}{l}\text { Cardiovascular risk } \\
\text { education and social } \\
\text { support }\end{array}$ & $\begin{array}{l}\text { Elaborate on a 3-year study of a practice-based intervention designed } \\
\text { to harness the power of social support to improve adherence to pre- } \\
\text { scribed treatments among diabetic patients with the ultimate goal of } \\
\text { reducing their risk of heart attack and stroke }\end{array}$ & $\begin{array}{l}\text { Kentucky Ambulatory } \\
\text { Network }\end{array}$ \\
\hline $\begin{array}{l}\text { Health services } \\
\text { research }\end{array}$ & $\begin{array}{l}\text { Practice improvement } \\
\text { project }\end{array}$ & $\begin{array}{l}\text { A study to assess the rates of influenza immunization in asthma } \\
\text { patients within the primary care practices to (1) identify the orga- } \\
\text { nizational and patient barriers to influenza immunization of asthma } \\
\text { patients, (2) randomize patients to dissemination of the research } \\
\text { findings, and (3) tailor interventions to improve immunization of } \\
\text { asthma patients }\end{array}$ & $\begin{array}{l}\text { Duke Primary } \\
\text { Care Research } \\
\text { Consortium }\end{array}$ \\
\hline
\end{tabular}

Table 5. Self-Assessed Strengths and Weaknesses of PBRNs ( $n=83$ reporting)

\begin{tabular}{lcc}
\hline & \multicolumn{2}{c}{ PBRNs Listing Characteristic } \\
\cline { 2 - 3 } Characteristic & $\begin{array}{c}\text { As a Strength } \\
\text { No. (\%) }\end{array}$ & $\begin{array}{c}\text { As a Weakness } \\
\text { No. (\%) }\end{array}$ \\
\hline Community involvement & $33(40)$ & $23(28)$ \\
Research experience & $29(35)$ & $15(18)$ \\
Data collection & $17(20)$ & $7(8)$ \\
Research administration & $15(18)$ & $6(7)$ \\
Information technology & $13(16)$ & $25(30)$ \\
Research design & $13(16)$ & $6(7)$ \\
Survey research & $11(13)$ & $4(5)$ \\
Data analysis & $10(12)$ & $5(6)$ \\
Ability to secure funding & $10(12)$ & $54(65)$ \\
Writing journal articles & $6(7)$ & $11(13)$ \\
\hline PBRN = practice-based research network. & \\
\hline
\end{tabular}

Existing PBRNs use a mixture of their own clinicians (bottom-up) and outside investigators (topdown) to choose research foci and individual projects. As a result, using PBRNs as a research resource will require efforts to establish more-effective communication among funding agencies, investigators, PBRN administrators, and PBRN clinicians. Furthermore, this communication should be bidirectional: (1) the PBRNs and their clinicians should be cognizant of the research interests and needs of federal and other funding agencies, and embrace those that are consistent with the needs and capabilities of the PBRNs and their practices; and (2) the funding agencies should use the PBRNs and their practices to better understand (and direct funds toward answering) the questions that everyday clinicians need answered so they can deliver high-quality, cost-effective care. 
Although most PBRNs are affiliated with universities, the 2 largest we surveyed are affiliated with professional organizations. Specifically, the American Academy of Family Physicians has established the AAFP National Research Network (formerly the National Network for Family Practice and Primary Care Research ${ }^{18}$ ), which includes 206 practices and 200,000 patients; and Pediatric Research in Office Settings ${ }^{19}$ is affiliated with the American Academy of Pediatrics and contains 1,760 practices and 2.7 million patients. The American College of Physicians also supports the American College of Physicians Network ${ }_{1}^{20}$ which at the time of this survey was 1 year old and growing, with 400 practices and 34,000 patients; as of this writing, it has 730 practices representing all 50 states. Affiliation with a national organization can facilitate a PBRN's involving a great many disparate practices with a wide geographic distribution that would improve external validity and generalizability of research results. In return, the PBRN provides the organization with a specialty-focused research venue that can serve the organization's specific research goals and objectives.

Funding PBRN activities, infrastructure, operations, and research projects is the principal barrier to realizing a PBRNs' potential as a research resource. Affiliation with universities and professional organizations provides some security to PBRNs, but this support could come with demands on access to the practices and research directions. Thus, financial dependency could deflect the PBRNs from their research mission and be responsible for the preponderance of top-down or mixed models of decision making about research directions and individual projects. Through a peer learning group facilitated by the AHRQ National Resource Center for Practice-Based Research Networks, ${ }^{21}$ the PBRNs are sharing experiences and evolving to more stable financial configurations.

This study has limitations. There was no central resource for identifying primary care PBRNs, and the definitions of what constitutes primary care and what is a PBRN, although formally established by AHRQ, are somewhat arbitrary. Our focus on primary care excluded the expanding number of disease-specific PBRNs, eg, those studying cancer ${ }^{22}$ and asthma, ${ }^{23}$ and those by disciplines other than medicine, eg, dentistry. ${ }^{24}$ Moreover, $20 \%$ of those primary care PBRNs we did identify declined to participate in this survey, which could bias our results. Also, many of the PBRNs we surveyed were young and could have matured or failed since the survey. Finally, our results may not be typical for primary care PBRNs in other countries, where PBRNs are older and more mature, and the relationships between generalists and specialists may differ substantially from those in the United States.

Nonetheless, PBRNs are gaining momentum and recognition both nationally and internationally. ${ }^{25}$ There is increasing interest in using PBRNs as a test-bed to address clinical and public health issues that are of great national interest. For example, one primary care PBRN and a consortium of primary care PBRNs were among the 12 research networks funded by the NIH Roadmap program, Re-Engineering the Clinical Research Enterprise, to initiate a national electronic research infrastructure. ${ }^{26}$ The Robert Wood Johnson Foundation funded 19 primary care PBRNs to study methods to help enhance patients' healthy behaviors. ${ }^{12}$ PBRNs have attracted the attention of several NIH institutes (including the National Institute of Mental Health, National Institute of Diabetes and Digestive and Kidney Diseases, National Heart, Lung, and Blood Institute, and National Cancer Institute) whose leaders see the potential of PBRNs as bidirectional venues for translating research into practice and practice into research. The funders of PBRN research and the PBRN community should collaborate on establishing a cogent research agenda, and the funding agencies should target funding programs toward PBRNs. The PBRNs should also collaborate among themselves to enhance their value as a network of PBRNs by sharing experiences (grasping opportunities and overcoming barriers) and collaborating on individual studies. Creative local and national investment in PBRNs will be necessary to continue their evolution into effective and productive primary care research laboratories and fulfill the $\mathrm{NIH}$ and AHRQ vision of "putting research into practice and practice into research." ${ }^{27}$

To read or post commentaries in response to this article, see it online at http://www.annfammed.org/cgi/content/full/5/3/242.

Key words: Research networks; primary care; survey research; practicebased research

Submitted February 7, 2006; submitted, revised, October 25, 2006; accepted November 11, 2006.

Findings from this study were presented as a poster at the 2004 national meeting of the Society of General Internal Medicine, May 12-14, 2004, Chicago, III.

Funding support: This work was supported by contract number 29002-0007 to Indiana University from the Agency for Healthcare Research and Quality.

Disclaimer: The opinions expressed are solely those of the authors and do not necessarily represent their institutions or the funding agency.

\section{References}

1. Institute of Medicine. Crossing the Quality Chasm: A New System for the 21st Century. Washington, DC: National Academy Press; 2001.

2. Balas E, Boren S. Managing Clinical Knowledge for Health Care Improvement. Yearbook of Medical Informatics 2000: Patient-centered Systems. Stuttgart, Germany: Schattauer; 2000. 
3. The NIH Roadmap: Accelerating medical discovery to improve health Available at: http://nihroadmap.nih.gov. Accessed: 16 October 2007.

4. Green LA, Fryer GE, Jr, Yawn BP, Lanier D, Dovey SM. The ecology of medical care revisited. N Engl J Med. 2001;344(26):2021-2025.

5. Schafer H. Post-approval drug research: objectives and methods. Pharmacopsychiatry. 1997;30(1 Suppl):4-8.

6. Kroenke K, Arrington ME, Mangelsdorff AD. The prevalence of symptoms in medical outpatients and the adequacy of therapy. Arch Intern Med. 1990;150(8):1685-1689.

7. Jackson JL, Kroenke K. The effect of unmet expectations among adults presenting with physical symptoms. Ann Intern Med. 2001;134(9 Pt 2):889-897.

8. S.580: Healthcare Research and Quality Act of 1999. Available at: http://www.ahrq.gov/hrqa99.pdf. Accessed 16 October 2006.

9. Thomas P, Griffiths F, Kai J, O'Dwyer A. Networks for research in primary health care. BMJ. 2001;322(7286):588-590.

10. Green LA, Simmons RL, Reed FM, Warren PS, Morrison JD. A family medicine information system: the beginning of a network for practicing and resident family physicians. J Fam Pract. 1978;7(3):567-576

11. Nelson EC, Kirk JW, Bise BW, et al. The Cooperative Information Project: Part 1: A sentinel practice network for service and research in primary care. J Fam Pract. 1981;13(5):641-649.

12. Green LA. Prescription for health: round 1 initial results. Ann Fam Med. 2005;3(Suppl 2):S2-S3.

13. Primary care practice-based research networks. Agency for Healthcare Research and Quality; Available at: http://grants.nih.gov/grants/ guide/rfa-files/rfa-hs-00-004.html. Accessed: 16 October 2006.

14. Federation of Practice-based Research Networks. Available at: http://www.aafp.org/online/en/home/clinical/research/fpbrn.html. Accessed: 16 October 2006.

15. Nutting PA, Beasley JW, Werner JJ. Practice-based research networks answer primary care questions. JAMA. 1999;281(8):686-688.

16. National Population Estimates-Characteristics (Table NA-EST2002ASRO-02). Population Division, United States Census Bureau; Available at: http://www.atmosfear.ro/popest/archives/2000s/vintage 2002/NA-EST2002-ASRO-02.html. Accessed: 16 October 2006.
17. Blackwell DL, Tonthat L. Summary health statistics for the U.S. population: National Health Interview Survey, 1999. Vital Health Stat 10. 2003;(211):1-94.

18. American Academy of Family Physicians. National research network. Available at: http://www.aafp.org/x3201.xml. Accessed: 16 October 2006

19. Wasserman RC, Slora EJ, Bocian AB, et al. Pediatric research in office settings (PROS): a national practice-based research network to improve children's health care. Pediatrics. 1998;102(6):1350-1357.

20. American College of Physicians. ACPNet Practice-Based Research Network. Available at: http://www.acponline.org/acpnet. Accessed: 16 October 2006.

21. Primary care practice-based research networks resource center. Available at: http://www.pbrnrc.iupui.edu. Accessed: 16 October 2006.

22. Greene SM, Hart G, Wagner EH. Measuring and improving performance in multicenter research consortia. J Natl Cancer Inst Monogr. 2005;(35):26-32

23. Kephart DK, Chinchilli VM, Hurd SS, Cherniack RM. The organization of the Asthma Clinical Research Network: a multicenter, multiprotocol clinical trials team. Control Clin Trials. 2001;22(6 Suppl):119S-125S.

24. Wotman S, Lalumandier J, Nelson S, Stange K. Implications for dental education of a dental school-initiated practice research network. J Dent Educ. 2001;65(8):751-759.

25. van Weel C, Rosser WW. Improving health care globally: a critical review of the necessity of family medicine research and recommendations to build research capacity. Ann Fam Med. 2004;2(Suppl 2): S5-S16

26. National Institutes of Health. NIH Roadmap: Accelerating medical discovery to improve health: Funded research. Available at: http:// nihroadmap.nih.gov/grants/fundedresearch.asp. Accessed: 16 October 2006.

27. Fraser I, Lanier D, Hellinger F, Eisenberg JM. Putting practice into research. Health Serv Res. 2002;37(1):xiii-xxvi. 